\title{
Albumen Foam Stability and S-Ovalbumin Contents in Eggs Coated with Whey Protein Concentrate ${ }^{(1)}$
}

Author(s)
Alleoni $\mathrm{ACC}^{2}$
Antunes $\mathrm{AJ}^{3}$
2 CNPq Fellowship
3 Universidade do Norte do Paraná, UNOPAR,
Londrina - PR, Brazil.

Mail Address

Ana Cláudia Carraro Alleoni Rua Athaualpa Vaz de Mello, 179 13.405-120 - Piracicaba, SP

E-mail: anaccarraro@terra.com.br

\section{Keywords}

Albumen foam, albumen proteins, s-ovalbumin, protein coating.

\section{Acknowledgement}

To Granja Bandeirantes, Comércio de Ovos e Cítricos, located in Sumaré, SP, for egg supply.

Part of the PhD Dissertation of the first author, Faculdade de Engenharia de Alimentos, Universidade Estadual de Campinas (Unicamp), SP, Brazil.

\section{ABSTRACT}

Food products such as breads, cakes, crackers, meringues, ice creams and several bakery items depend on air incorporation to maintain their texture and structure during or after processing. Proteins are utilized in the food industry since they improve texture attributes through their ability to encapsulate and retain air. The objectives of this work were to quantify s-ovalbumin contents in albumen and to determine alterations in egg white foam stability in fresh eggs, and in eggs coated and noncoated with a whey protein-based concentrate film (WPC), stored at $25^{\circ} \mathrm{C}$ for 28 days. The volume of drained liquid was higher in non-coated eggs than in coated eggs stored at $25^{\circ} \mathrm{C}$ at all storage periods. The difference on the third day of storage was in the order of $59 \%$ between coated and non-coated eggs, while on the twenty-eighth day it was $202 \%$. During the storage period, an increase in $\mathrm{pH}$ and drainage volume was observed for non-coated eggs. After three days, the non-coated eggs showed a s-ovalbumin content 33\% higher than coated eggs; this increase jumped to $205 \%$ at 28 days of storage. There was a positive correlation between s-ovalbumin content and the volume of drained liquid for coated and non-coated eggs; in other words, when the sovalbumin content increased, there was an increase in the volume of drained liquid and a decrease in foam stability. WPC coating maintain egg quality, since it is an effective barrier against the loss of $\mathrm{CO}_{2}$, avoiding changes in the $\mathrm{pH}$ of egg white.

\section{INTRODUCTION}

Foams are used in the food industry in the manufacture of breads, cakes, crackers, meringues, ice creams, and several other bakery products (Pernell et al., 2002). These food products depend on air incorporation to maintain their texture and structure during or after processing. Proteins encapsulate and retain air, improving desirable textural attributes (Phillips et al., 1994). Proteins form and stabilize foam due to their amphilic behavior (polar/non-polar) (Du et al., 2002).

Foaming properties of albumen are affected by several factors, such as protein concentration (Britten \& Lavoie, 1992), composition (Johnson \& Zabik, 1981), pH (Hammershfj et al., 1999), ionic strength (Kato et al., 1983), intermolecular interactions (Kinsella, 1984), heating, presence of salts, and composition of the liquid phase (Du et al., 2002), which may change the configuration and the stability of protein molecules. These changes might affect the formation of the film and its properties on the interface, thus modifying foaming properties (Du et al., 2002).

Egg white is a mixture of proteins that possess excellent foaming properties, since each of its components performs a specific function. Globulins facilitate foam formation, while the ovomucin-lysozyme complex (Cotterill \& Winter, 1955) confers stability to the foam, and 
both ovalbumin and conalbumin are heat-related (Yang \& Baldwin, 1995). Conalbumin, lysozyme, ovomucin, and ovomucoid alone have little or no foaming ability, but the interaction between lysozyme and globulin is important to foam formation (Johnson \& Zabik, 1981).

Ovalbumin is the largest protein in egg white and it contributes to foam formation properties in food systems where eggs are utilized as an ingredient. This phosphoglycoprotein represents $54 \%$ of the total protein in the albumen. S-ovalbumin is derived from ovalbumin, and was first reported by Smith (1964) and Smith \& Back (1965). It is formed during the period of storage of shelled eggs and in ovalbumin solutions. There is no difference in aminoacid composition between ovalbumin and s-ovalbumin. Ovalbumin deamidation may occur under alkali treatment or through egg white storage (Kato et al., 1986). In most cases, the transformation of ovalbumin into s-ovalbumin brings about an increase in $\mathrm{pH}$ and temperature.

The constituents of heterogeneous protein systems, such as the egg white, have different isoelectric points and exhibit different charges. In the egg white, the electrostatic interactions contribute to the formation of an excellent heat-stable foam (Johnson \& Zabik, 1981).

Coated eggs keep internal quality due to the reduction of the breakage of eggshell and egg microbial contamination (Wong et al., 1995). Edible coating maintains the functional properties of foods by decreasing moisture loss and gas transport $\left(\mathrm{O}_{2}\right.$ and $\left.\mathrm{CO}_{2}\right)$ (Donhowe \& Fennema, 1994). Edible biopolymer coating made from whey proteins has attracted an increasing amount of research and industry attention, since it is an alternative of food packaging with reduced environmental and waste-disposal costs (Fang et al., 2002).

The objective of this study was to evaluate changes in albumen $\mathrm{pH}$, in egg white foam stability through drainage, and in s-ovalbumin contents in egg whites of chicken eggs coated with a whey protein concentrate, as a function of storage periods.

\section{MATERIAL AND METHODS}

Eggs were collected right after laying in a poultry farm located in Sumaré - SP, Brazil. We utilized eggs from Hy-line w36 laying hens fed maize-based diet. The eggs were sanitized with $1 \%$ sodium hypochlorite for $30 \mathrm{~s}$. A group of dried eggs were then immersed for 1 min in a solution of whey protein concentrate (WPC), and dried at ambient temperature for $24 \mathrm{~h}$. A second group of eggs was not coated.
Eggs were stored in egg cartons, inside a BOD (Biological Oxygen Demand) incubator at $25^{\circ} \mathrm{C}$. Determinations were made with three replicates per method and per analysis, at 3, 7, 10, 14, 21 and 28 days of storage. The experimental design was a $2 \times 6$ factorial arrangement, in which the main sources of variation were coating and time.

The coating solution was prepared according to the methodology described by Gennadios et al. (1993), containing $8 \%$ protein from the whey protein concentrate (WPC), 3.5\% glycerol, and completed with $100 \mathrm{~g}$ water $(\mathrm{w} / \mathrm{w})$. The solution was homogenized and submersed in water at $90^{\circ} \mathrm{C}$ for $30 \mathrm{~min}$. After cooling to $25^{\circ} \mathrm{C}$, pH was adjusted to 7.0 with $1.0 \mathrm{~N} \mathrm{NaOH}$.

The albumen $\mathrm{pH}$ was obtained with a Micronal B374 potentiometer. The egg white was separated from the yolk. After stirring lightly, $\mathrm{pH}$ was obtained. Foam stability was measured by the Mckellar \& Stadelman (1955) method. Egg whites (28g) were placed in a 250$\mathrm{mL}$ plastic beaker and kept in a double boiler until the temperature of the egg white reached $30^{\circ} \mathrm{C}$. The egg whites were beaten for $120 \mathrm{~s}$ (value in the range recommended by Trziszka, 1993) at 2,200 rpm with a brand multimixer. The amount of drainage was measured with a graduated cylinder after the foam was allowed to rest for $30 \mathrm{~min}$.

The s-ovalbumin content of the egg white was measured by the method of Smith \& Nguyen (1984). Five grams of egg whites were placed in a $100-\mathrm{mL}$ beaker, and $25 \mathrm{~mL}$ of $0.5 \mathrm{M}$ phosphate buffer $\mathrm{pH} 7.5$ were added; the mixture was agitated for 5 min with a magnetic stirrer. Afterwards, $5 \mathrm{~mL}$ of the suspension were placed in two test tubes; one of the tubes was heated at $75^{\circ} \mathrm{C}$ for $30 \mathrm{~min}$. Upon cooling, $5 \mathrm{~mL}$ precipitating solution were added and the solution was transferred to centrifuge tubes, with the addition of another $5 \mathrm{~mL}$ precipitating solution. After resting for $10 \mathrm{~min}$, the tubes were centrifuged at 10,000 rpm for $5 \mathrm{~min}$ and the supernatant was filtered. Two $\mathrm{mL}$ of the supernatant was placed in a test tube with $4 \mathrm{~mL}$ Biuret solution. This supernatant aliquot was left to rest for $30 \mathrm{~min}$, and the absorbance was read at $540 \mathrm{~nm}$, in a Beckman DU-70 spectrophotometer.

Multiple comparisons of the means were performed for statistical analysis involving storage times and coating and non-coating process. An orthogonal contrast (treatments $x$ fresh eggs) was applied. Means were compared by Tukey's test, when applicable. 


\section{RESULTS AND DISCUSSION}

The statistical analyses for volume of drained liquid from egg white foam and for s-ovalbumin content indicated that there were interactions between coating and storage time. Therefore, regressions were applied in both cases, and the results were interpreted within each storage period. Results from fresh egg (day 0 ) were used as reference.

\section{Foam Stability (expressed as drainage)}

In all storage periods, the volume of drained liquid from the albumen foam was greater in the non-coated eggs (Table 1). As time passed, the films became progressively thinner and ruptured. Throughout the storage period, the fluid is lost by lamellar water drainage, resulting in a foam collapse (Phillips, 1981). During drainage, the van der Waals forces increase between films in adjacent bubbles (Phillips et al., 1994).

On the $3^{\text {rd }}$ day of storage, the difference in drainage volume was in the order of $59 \%$ between coated and non-coated eggs, while on the $28^{\text {th }}$ day it was $202 \%$. The results for volume of drained liquid were fitted to linear regressions with $r^{2}=0.86$ for non-coated eggs, and $r^{2}=0.84$ for coated eggs. The $\mathrm{pH}$ and the volume of drained liquid in coated eggs were 8.01 and $1.5 \mathrm{~mL}$, respectively (Table 1$)$. In non-coated eggs, the $\mathrm{pH}$ was 9.09 , and the volume was $2.38 \mathrm{~mL}$, in the same period. At 28 days of storage, the difference between coated and non-coated eggs was greater (Table 1), with a $13.3 \%$ increase between $\mathrm{pH}$ values, and a $202 \%$ increase between drainage values. Thus, the amount of liquid drained from the egg white foam of non- coated eggs was three times greater than in coated eggs within this $\mathrm{pH}$ range.

The $\mathrm{pH}$ in the aqueous phase determines the magnitude and the nature of protein charges and therefore affects the foam (Kinsella \& Phillips, 1989). The $\mathrm{pH}$ values in egg whites of coated eggs were always smaller than the values for non-coated eggs (Table 1). This could be due to the effect of coating on impairing albumen $\mathrm{CO}_{2}$ loss through the shell, which would prevent expressive increases in $\mathrm{pH}$.

During the entire storage period, the albumen $\mathrm{pH}$ of coated eggs remained around 8 , while the variation in volume of drained liquid was $1.5 \mathrm{~mL}$ at three days and $3.3 \mathrm{~mL}$ at the end of the period. The foam stability behavior could be related to the pl values of most egg white proteins, which are between 4 and 6 . Thus, proteins are negatively charged in the albumen. The positively charged lysozyme $(\mathrm{pl}=10.7)$ has a vital role in the formation and stability of the egg's albumen foam (Poole et al., 1984). During foam formation, lysozyme and other negatively charged proteins may migrate to the air-liquid interface. On this interface, lysozyme interacts electrostatically with other negatively charged proteins, causing a reduction in the repulsive electrostatic interactions on the protein layer and in albumen foam stabilization (Poole et al., 1984; Clark et al., 1988; Damodaran, 1989; Damodaran, et al., 1998).

Considering only the non-coated eggs, an increase in $\mathrm{pH}$ and drainage volume was observed during the storage period. The high drained liquid value is related to an increase in egg white $\mathrm{pH}$, which interferes in the lamellar fluid viscosity, causing an approximation between the adjacent air bubbles. Consequently, bubble rupture and coalescence will occur, resulting in

Table 1 - Volume of drained liquid, s-ovalbumin contents and $\mathrm{pH}$ of egg white foam stored at $25^{\circ} \mathrm{C}$, as a function of storage period and coating with whey protein-based film (WPC).

\begin{tabular}{|c|c|c|c|c|}
\hline Storage Period & Coating (WPC) & pH Albumen & Drained Liquid ML & S-ovalbumin $\%$ \\
\hline Fresh egg & - & $7.93 d \pm 0.16$ & $1.08 j \pm 0.04$ & $18.15 k \pm 0.13$ \\
\hline \multirow{2}{*}{3 days } & With ${ }^{1}$ & $8.01 d \pm 0.13$ & $1.50 \mathrm{i} \pm 0.03$ & $18.52 j \pm 0.06$ \\
\hline & Without & $9.09 b \pm 0.17$ & $2.38 h \pm 0.04$ & $24.68 \mathrm{~g} \pm 0.31$ \\
\hline \multirow[t]{2}{*}{7 days } & With & $8.03 d \pm 0.10$ & $2.36 h \pm 0.16$ & $23.33 \mathrm{hi} \pm 0.32$ \\
\hline & Without & $9.24 b \pm 0.06$ & $5.04 d \pm 0.15$ & 55.02 e \pm 0.56 \\
\hline \multirow[t]{2}{*}{10 days } & With & $8.07 c d \pm 0.15$ & $2.59 \mathrm{gh} \pm 0.19$ & $23.21 \mathrm{i} \pm 0.13$ \\
\hline & Without & $9.35 a b \pm 0.06$ & $6.28 c \pm 0.08$ & $61.99 d \pm 0.27$ \\
\hline \multirow{2}{*}{14 days } & With & $8.21 \mathrm{c} \pm 0.10$ & $2.89 f \pm 0.05$ & $22.95 i \pm 0.25$ \\
\hline & Without & $9.47 a \pm 0.10$ & $8.52 b \pm 0.23$ & $65.34 c \pm 0.44$ \\
\hline \multirow[t]{2}{*}{21 days } & With & $8.23 c \pm 0.14$ & $2.89 \mathrm{fg} \pm 0.17$ & $23.86 \mathrm{gh} \pm 0.55$ \\
\hline & Without & $9.46 a \pm 0.08$ & $9.86 a b \pm 0.12$ & $72.75 b \pm 0.77$ \\
\hline \multirow[t]{2}{*}{28 days } & With & $8.33 c \pm 0.17$ & $3.30 \mathrm{e} \pm 0.12$ & $26.71 f \pm 0.07$ \\
\hline & Without & $9.44 a \pm 0.08$ & $9.96 a \pm 0.08$ & $81.46 a \pm 0.58$ \\
\hline
\end{tabular}

1 - Means in the columns followed by same letter are not different ( $p>0.05)$. 
liquid drainage and foam destabilization (Phillips et al., 1994).

Even though the positive effect of lysozyme on the properties of several acid proteins can be experimentally observed, there is no direct evidence of the formation of an electrostatic complex between lysozyme and the acid proteins in the film absorbed on the air-water interface (Damodaran et al., 1998). However, several acid proteins form insoluble electrostatic complexes with lysozyme (Poole et al., 1984; Damodaran \& Kinsella, 1986), and insoluble complexes are usually not good foaming agents (Damodaran et al., 1998).

\section{S-Ovalbumin}

S-ovalbumin content was higher in non-coated eggs in all storage periods (Table 1). At three days, the noncoated eggs showed a content 33\% higher in relation to coated eggs. At 28 days of storage, however, this difference was three times higher.

The $\mathrm{pH}$ in coated eggs stored at $25^{\circ} \mathrm{C}$ was around 8 , and the s-ovalbumin content remained around $18 \%$. Only at the 28th day its content reached $27 \%$. Alleoni (1997) worked with periods and two chicken egg storage temperatures, and obtained similar values at the refrigeration temperature as those obtained for coated eggs in the present study. That author reported s-ovalbumin contents equal to $18.4 \%, 26.2 \%$ and $24.3 \%$ in eggs storage at $8^{\circ} \mathrm{C}$ for 7,14 , and 21 days, respectively. In the present study, the s-ovalbumin values of coated eggs were $23.3 \%, 22.9 \%$ and $23.9 \%$, for the same storage periods. When the eggs were stored at $25^{\circ} \mathrm{C}$, Alleoni (1997) obtained $55.7 \%$, and $69.3 \%$, for 7 and 14 days, respectively, while in the present work, contents were $55.0 \%$ and $65.3 \%$ in the same storage periods. Therefore, WPC coating had the same effect as the refrigeration temperature.

Ovalbumin can be adsorbed in aqueous solutions on the air-water interface and acts as a surfactant, reducing the surface tension and forming a cohesive film. The behavior of proteins on air-water interfaces influences the formation and stability of foam (Du et al., 2002). As the $\mathrm{pH}$ increases, part of the egg white ovalbumin is transformed into s-ovalbumin. In view of this, the amount of ovalbumin in the egg white decreases, and this could interfere with the formation of a cohesive film on the air-water interface, causing a decrease in foam stability. S-ovalbumin is less hydrophobic than ovalbumin (Nakamura et al., 1980; Schäfer et al., 1999).

Hagolle et al. (2000) obtained the best foaming properties at $85^{\circ} \mathrm{C}$ for ovalbumin and at $75^{\circ} \mathrm{C}$ for lysozyme; these temperatures are near the denaturation temperature of both proteins. As heat is applied, the tertiary and the secondary structures of the ovalbumin molecule become denatured, causing strong hydrophobic interactions between proteins, which lead to aggregation (Du et al., 2002). It is possible to stabilize foams using denatured ovalbumin (Relkin et al., 1999). Under acidic conditions, ovalbumin has greater flexibility and surface hydrophobicity.

Ovalbumin plays an important role in egg white foam stability (Relkin et al., 1999; Hagolle et al., 2000; Du et al., 2002). Considering the results obtained for non-coated eggs at 28 days of storage, in which the s-ovalbumin content reached $80 \%$ and the amount of ovalbumin in the egg white decreased, a greater loss of egg white foam stability was observed in that storage period.

Schäfer et al. (1999) stored eggs for six weeks at $30^{\circ} \mathrm{C}$ and evaluated the composition of proteins in the egg white. No changes in lysozyme activity or in the amount of conalbumin were observed during storage. However, the ovalbumin pl decreased, which is in agreement with the formation of s-ovalbumin during storage. Changes were more influenced by temperature than storage period.

In eggs stored without coating, the activity of lysozyme does not decrease during storage, and the amount of conalbumin does not change (Schäfer et al., 1999). Therefore, the s-ovalbumin contents increase in the same proportion as the volume of drained liquid. In the present work, the smallest values for volume of drained liquid and for s-ovalbumin contents were obtained with coated eggs. Under these conditions, the $\mathrm{pH}$ was maintained near 8 . The smallest rate of conversion of ovalbumin into s-ovalbumin is verified at pH 8.5 (Smith \& Nguyen, 1984).

In non-coated eggs, egg white $\mathrm{pH}$ varied from 9.1 to 9.4 during the storage period, while the volume of drained liquid ranged between 2.38 and $9.96 \mathrm{~mL}$ (Table 1), and the s-ovalbumin contents ranged between 24.7 and $81.5 \%$ (Table 1). Thus, this protein could be related to a decrease in foam stability, despite the fact that the mechanisms involved are still unknown. The correlation between s-ovalbumin content and the volume of drained liquid were positive for both coated and noncoated eggs (Figures 1 and 2).

As s-ovalbumin content increased, the volume of drained liquid also increased, i.e., foam stability decreased. Therefore, it can be concluded that WPC coating maintain egg quality, since it is an effective barrier against the loss of $\mathrm{CO}_{2}$, avoiding changes in the $\mathrm{pH}$ of egg white. 


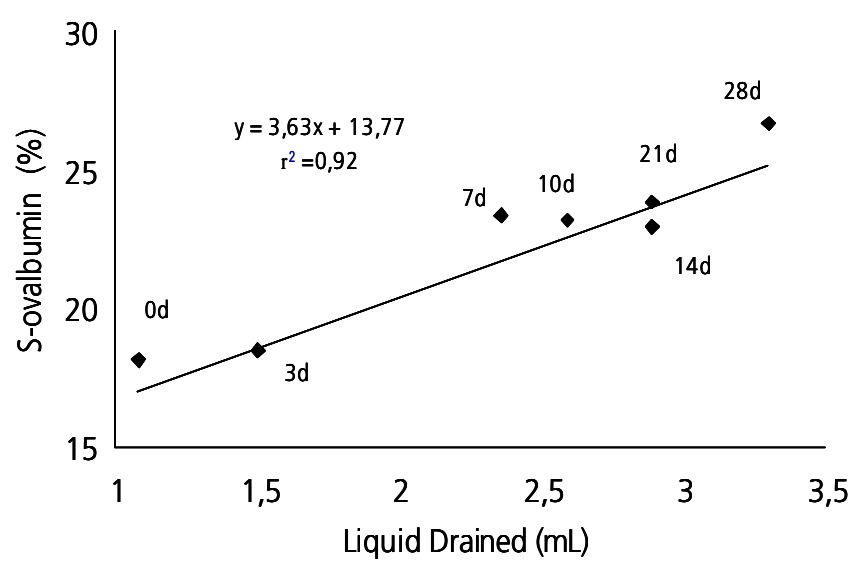

Figure 1 - Linear correlation between the volume of drained liquid and s-ovalbumin contents of coated eggs, during the storage period.

\section{REFERENCES}

Alleoni ACC. Efeito da temperatura e do período de armazenamento na qualidade do ovo, nos teores de s-ovalbumina e nas propriedades funcionais das proteínas da clara do ovo.[Dissertação]. Campinas (SP): Universidade Estadual de Campinas; 1997.

Britten M, Lavoie L. Foaming properties of proteins as affected by concentration. Journal of Food Science 1992; 57:1219-1222.

Clark DC, Mackei AR, Smith LJ, Wilson D. The interaction of bovine serum albumin and lysozyme and its effect on foam composition. Food Hydrocolloids 1988; 2:209-223.

Cotterill OJ, Winter AR. Egg white lysozyme. 3. The effect of $\mathrm{pH}$ on the lysozyme-ovomucin interaction. Poultry Science 1955; 34:679-686

Damodaran S. Interrelationship of molecular and functional properties of food proteins. In: Kinsella, J.E., Souci, W.G. editors. Food proteins. Champaign: AOCS, 1989. p.21-51.

Damodaran S, Kinsella JE. Role of electrostatic forces in the interaction of soy proteins with lysozyme. Cereal Chemistry 1986; 6:381-383.

Damodaran S, Anand K, Razumovsky L. Competitive adsorption of egg white at the air-water interface: Direct evidence for electrostatic complex formation between lysozyme and other egg proteins at the interface. Journal of Agriculture and Food Chemistry 1998; 46(3):872-876.

Donhowe G, Fennema O. Edible films and coatings: characteristics, formation, definitions, and testing methods. In: Krochta, J.M.; Baldwin, E.A.; Nisperos-Carriedo, M.O. (Ed.) Edible coatings and films to improve food quality. Lancaster: Technomic Publishing, 1994. p.1-24.

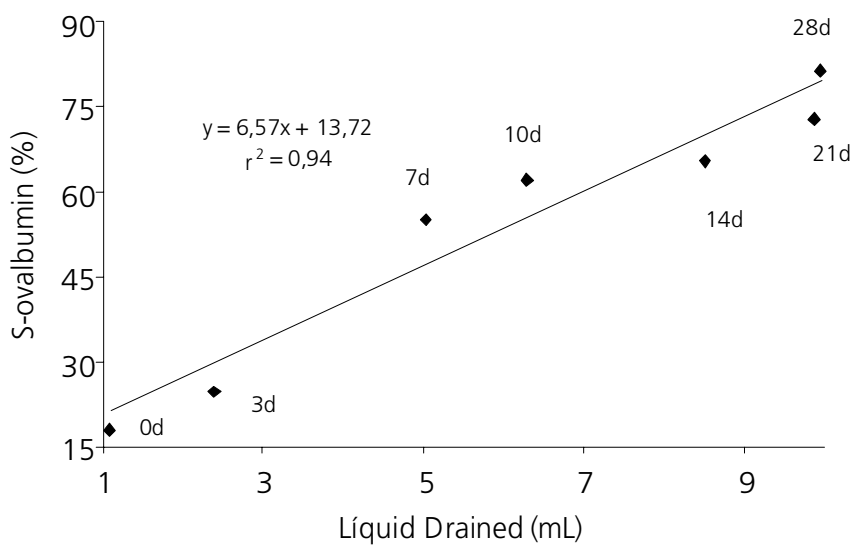

Figure 2 - Linear correlation between the volume of the drained liquid and s-ovalbumin contents of non-coated eggs, during the storage period.

Du L, Prokop A, Tanner RD. Effect of denaturation by preheating on the foam fractionation behavior of ovalbumin. Journal of Colloid and Interface Science 2002; 248:487-492.

Fang Y, Tung MA, Britt IJ, Yada S, Dalgleish DG. Tensile and barrier properties of edible films made from whey proteins. Journal of Food Science 2002; 67(1):188-193.

Gennadios A, Brandenburg CL, Weller CL, Testin RF. Effect of pH on properties of wheat gluten and soy protein isolate films. Journal of Agriculture and Food Chemistry 1993; 11:1835-1839.

Hagolle N, Relkin P, Popineau Y, Bertrand D. Study of the stability of egg white protein-based foams: effect of heating protein solution. Journal of the Science of Food and Agriculture 2000; (80):1245-1252.

Hammershøj M, Prins A, Qvist KB. Influence of $\mathrm{pH}$ on surface properties of egg albumen solutions in relation to foaming behavior. Journal of the Science of Food and Agriculture 1999; 79:859-868.

Johnson TM, Zabik ME. Egg albumen proteins interactions in an angel food cake system. Journal of Food Science 1981; 46:20712083.

Kato A, Takahashi A, Matsudomi N, Kobayashi K. Determination of foaming properties of proteins by conductivity measurements. Journal of Food Science 1983; 48:62-65.

Kato A, Tanaka A, Matsudomi N, Kobayashi K. Deamidation of ovalbumin during s-ovalbumin conversion. Agricultural Biological Chemical 1986; 50(9):2375-2380.

Kinsella JE. Milk proteins: physicochemical and functional properties. CRC Critical Review Food Science and Nutrition 1984; 21(2):197262. 
Kinsella JE, Phillips LG. Structure function relationships in food proteins: films and foaming behavior. In: Kinsella J.E., Souncie, W.G. (Ed.). Food Proteins. AOCS, Champaign, IL. 1989. p.52-77.

Mckellar MB, Stadelman WJ. A method for measuring volume and drainage of egg white foams. Poultry Science 1955; 34:455-458.

Nakamura R, Takayama M, Nakamura K, Umemura O. Constituent proteins of globulin fraction obtained from egg white. Agricultural Biological Chemical 1980; 44:2357-2360

Pernell CW, Foegeding EA, Luck PJ, Davis JP. Properties of whey and egg white foams. Colloids and Surfaces 2002; 204:9-21.

Phillips LG. Protein conformation at liquid interfaces and its role in stabilizing emulsions and foams. Food Technology 1981; 35:5051,54-57.

Phillips LG, Whitehead DM, Kinsella JE. Structure-function properties of food proteins. San Diego: Academic Press, 1994. 271p. (Food Science and Technology International Series).

Poole S, West SI, Walters CL. Protein-protein interactions: Their importance in the foaming of heterogeneous protein systems. Journal of Agricultural and Food Chemistry 1984; 35:701-711.

Relkin P, Hagolle N, Dalgleish DG, Launay B. Foam formation and stabilisation by pre-denatured ovalbumin. Colloids and Surfaces B: Biointerface 1999; 12:409-416.

Schäfer A, Drewes W, Schwägele F. Effect of storage temperature and time on egg white protein. Nahrung 1999; 43(2):86-89.

Smith MB. I-Denaturation by heat, and the heterogeneity of ovalbumin. Australian Journal Biological Science 1964; 17:261-670.

Smith MB, Back JF. Studies on ovalbumin. II - The formation and properties of the s-ovalbumin, a more stable form of ovalbumin. Australian Journal Biological Science 1965; 18:365-377.

Smith MB, Nguyen L. Measuring the age of stored eggs. CSIRO Food Research Q. 1984; 44:94-96.

Trziszka T. Protein aggregation whipping of egg white and its effect on the structure and mechanical properties of foams. Archiv fur Geflugelkunde 1993; 57(1):24-28

Wong YC, Herald TJ, Hachmeister KA. Evaluation of mechanical and barrier properties of coatings on shell eggs. Poultry Science 1995; 75:417-422.

Yang SC, Baldwin RE. Functional properties of eggs in foods. In: Stadelman, W.J., Cotterill, O.J. (Ed.). Egg science and technology. 4.ed. Binghamton: Food Products Press; Haworth Press, 1995. p.405-463. 